Mitteilungen der Österreichischen Geographischen Gesellschaft,

155. Jg. (Jahresband), Wien 2013, S. 105-124

\title{
Migration
}

\section{Amenity Migration in the Southern Andes and the Southern European Alps - A Key Factor for Sustainable Regional Development?}

\author{
Oliver BENDER, and Sigrun KANITSCHEIDER, both Innsbruck*
}

with 4 Fig. in the text

\section{CONTENTS}

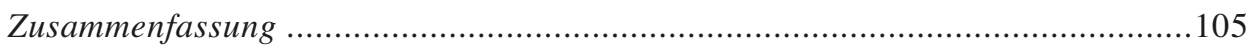

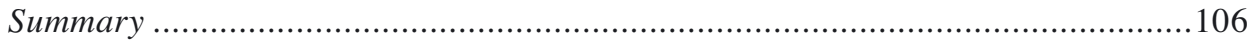

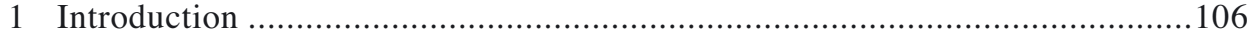

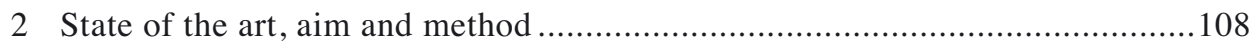

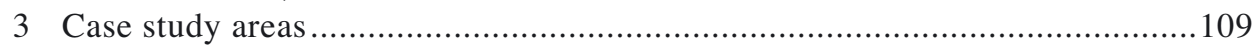

4 Discussion: Comparing the southern European Alps and southern Andes .......117

5 Conclusion and brief outlook: Opportunity or risk for a sustainable

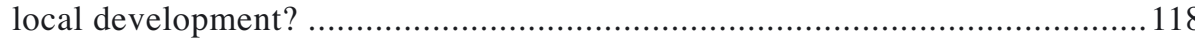

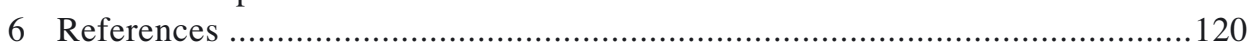

\section{Zusammenfassung}

Amenity Migration in die südlichen Anden und südlichen Alpen - ein Erfolgsfaktor für nachhaltige Regionalentwicklung?

Über lange Zeit waren ländliche Gebirgsregionen in vielen Ländern Abwanderungsgebiete, insbesondere von jungen und gut ausgebildeten Bevölkerungsteilen. Erst in den letzten Jahrzehnten ist in manchen Periphergebieten ein gegenläufiger Prozess zu beobachten: die „Amenity Migration“. Diese „neue Zuwanderung “ zielt häufig in landschaftlich reizvolle, klimatisch angenehme Gebiete, die in vielen Fällen schon

\footnotetext{
* Dipl.-Geogr. PD Dr. Oliver Bender, Dipl.-Geogr. Dr. Sigrun Kanitscheider, Institut für Interdisziplinäre Gebirgsforschung, Österreichische Akademie der Wissenschaften, Technikerstraße 21a, Otto-HittmairPlatz 1, A-6020 Innsbruck; e-mail: oliver.bender@oeaw.ac.at, sigrun.kanitscheider@oeaw.ac.at, http:// www.mountainresearch.at
} 
über längere Zeiträume touristisch genutzt worden sind. Dabei zeigen Fallstudien aus verschiedenen Gebirgslandschaften eine beträchtliche Mannigfaltigkeit bei den Zuwanderergruppen und den von ihnen jeweils präferierten Zielgebieten.

Auf der Grundlage von quantitativen wie qualitativen Methoden untersucht dieser Beitrag die Amenity Migration in jeweils zwei Teilräume der südlichen Alpen und der südlichen Anden. Insbesondere werden der zeitliche Beginn und die Intensität der Wanderungsprozesse sowie die Motivation und soziodemographischen Charakteristika der Zuwanderer miteinander verglichen. Der Beitrag schließt mit einer Abschätzung, welche Bedeutung die Amenity Migration für die Entwicklung der Zielregionen besitzt und welche Auswirkungen sie für die autochthonen Bevölkerungen mit sich bringt.

\section{Summary}

For a long time, peripheral rural mountain regions in many countries were marked by emigration, particularly that of the young and well qualified. In recent decades, we can observe an apparently diametrical process in some regions: 'amenity migration', which implies the migration to remote, rural areas. This 'new immigration' is targeted at areas of natural beauty and favourable climatic conditions, many of them already known as tourist destinations. Several case studies for different mountain regions show a great variety, both of the migrating persons and the chosen destinations.

Based on quantitative and qualitative methods, this paper examines four case study areas in different regions of the southern European Alps and the southern Andes and compares the onset and the intensity of the process, the motivation and the characteristics of the migrants and the significance of this phenomenon for regional development in the target regions. It ends by discussing opportunities and risks for the local population.

\section{Introduction}

Peripheral rural regions very often suffer from emigration, losing especially the young and qualified segments of the population who, seeking better education and employment opportunities, migrate to economically more active regions. As a consequence, the older, less mobile, less educated and socio-economically deprived sections of the population remain in these regions. Frequently the infrastructure to supply those left behind with necessary goods and services have to be reduced (cf. e.g. TAPPEINER et al. 2008 for the Alps; Grau \& Aide 2007 for the Andes).

The consequences of outmigration for the remaining population can be dramatic. The shortfall in municipal revenues - result of the decreasing number of inhabitants restricts the financial scope of the community; reduced demand causes an economically less attractive situation for local suppliers, service centres and other infrastructures; the age-selective migration inhibits innovations fostered usually by young and edu- 
cated people and therefore reinforces the ongoing process (cf. e.g. BäTZING 2003 and TAPpeiner et al. 2008 for the Alps; Garín Contreras \& Albers 2011 with an example for the Andes).

However, in some peripheral regions, we can observe an apparently diametrical process: 'amenity migration', which often implies the migration to remote, rural areas. The concept of amenity migration goes back to studies conducted by Graves (e.g. 1980) and later Moss (1994) in North America. Amenity migration is seen as the opposite of (labour) migration for economic reasons while amenities might be the landscape or socio-cultural factors (PERLIK 2006). A German translation of the term (,Wohlstandswanderung“, PerLik 2007, p. 123, which means 'affluence migration') reveals that the protagonists of amenity migration come from the middle and upper socio-economic classes. The characteristic features following STEWART (2002) are: a voluntary migration not motivated by economic or political reasons, from urban to rural spaces perceived as particularly attractive. Some of these migrants are still working and often accept personal economic losses as a result of lower incomes in the target regions.

The definition of the term 'amenity migration', however, is not unambiguous and overlaps with other types of migration, for example, returnee migration, neoruralism or even tourism with second homes and multilocal living in general (see BENDER \& KANITSCHEIDER 2012; cf. the different definitions given in the survey provided by CHipeniuk 2008). Used for similar processes, though not synonymous, is the term "counter-urbanization" (BERRY 1980) referring to urban-rural migration into attractive residential areas (cf. Löffler \& Steinicke 2006; KAHSAi \& Schaeffer 2010).

The decision to transfer the principal residence is very often preceded by different stages of temporary stays. Initially a single vacation, which is subsequently repeated, eventually the establishment of a weekend or leisure residence and finally the transfer of the principal residence to the region (STEWART 2002). Nevertheless, very often the final step of transferring the principal residence does not occur and two or more residences are maintained (bi- or multilocal dwelling) (PerLik 2011). This, at least statistical, problem is exacerbated by the different ways in which such primary and secondary residences are captured by the different countries (BENDER \& KANITSCHEIDER 2012). As a consequence, research on amenity migration must be seen in the wider functional context of multilocal living (see PERLIK 2011). The concept of multilocality has already been discussed by McIntyre (2009) and WeichHart (2009). Multilocality is quite cost-intensive and for this reason dependent on a certain social position. PERLIK (2011), referring back to PHILliPs (1993), therefore speaks of "Alpine gentrification" in the case of the Alps.

Amenity migrants choose their future places of residence according to different criteria, such as natural beauty, favourable climatic conditions and attractive social and cultural choices as well as touristic infrastructure. Many of the target regions are already known as tourist destinations (cf. Moss 2006), and mountain regions are among the most popular for these migrants as numerous studies all over the world have shown (cf. Bender \& Kanitscheider 2012; Glorioso \& Moss 2007; NAKayama \& MARIONI 2007). 


\section{State of the art, aim and method}

In recent years, amenity migration in mountain regions has become a research focus not only in Europe (e.g. PERLiK 2011 for the whole of the Alpine region; STEINICKE et al. 2010 as well as BeISMANn et al. 2011 for the Italian Alps; Fourny 1994 with an early study for Savoy [Savoie]/France, as well as CognARd 2006 for the southern French Alps; LÖfFler \& STEINICKe 2006 and 2007 for the Sierra Nevada/California; cf. the proceedings of the Banff conference edited by Moss et al. 2009). Case studies from Costa Rica (Chaverri 2006) and Argentina (Otero et al. 2006; GonzÁlez et al. 2009) as well as Chile (HIDALGo et al. 2009) reveal that in Latin America amenity migration with different characteristics is also a well-known phenomenon.

Given the demographic change and its beneficial effects to economies (cf. BLOOM \& CANNING 2004), amenity migration will become more significant and relevant for the competitiveness of the target regions of these migration flows (cf. BENDER \& Kanitscheider 2012). The destinations would benefit from attracting affluent and/or economically active people who can look after themselves and bring an added value to the municipality, ideally reproducing themselves. This idea of specifically encouraging amenity migration as a demographic process and taking (economic) advantage of it within the target regions has been expressed by CHIPENIUK (2005). However, there is still a lack of studies presenting results about the opportunities and risks for regional development, especially in mountain regions (as already stated by GLORIOSO \& Moss 2007).

This paper therefore aims to (re)evaluate and discuss existing studies of amenity migration in terms of its potential for sustainable development. The chosen study regions - southern Alps and southern Andes - have become prime targets for amenity migrants (cf. Moss 2006). Both regions are in a similar natural situation (mountain environments close to the Mediterranean and temperate climate zones), but offer interesting options for a comparison between 'developed' and 'newly industrialising countries' with their different socio-demographic statuses. This also means that the fundamental circumstances and the development of amenity migration in each case study area need to be looked at closely.

The leading questions for this paper are:

- To which extent does the phenomenon of amenity migration exist in the Alps and the Andes?

- When did the process start?

- Is it possible to quantify the intensity?

- What are motivating factors for the migrants?

- Can the amenity migration in the Alps/Andes be seen as a contribution to sustainable regional development?

This paper is based on a comparative evaluation of case studies from different areas in the southern Alps and Andes; one of these studies was conducted by the authors themselves (East Tyrol [Osttirol]). As the underlying case studies have not been carried out for comparative purposes, they can only serve as complementary information. In these case studies, both quantitative (evaluation of official demographic statistics) and 
qualitative methods (guided as well as narrative interviews with the amenity migrants themselves, interviews with experts, mainly players from local politics and tourism, field mapping) were implemented, however, the studies differed in focus and depth of investigation.

\section{Case study areas}

\subsection{Italian Alps}

For the Italian Alps, we will outline the spatial distribution patterns of amenity migration, both from a local and a (larger) regional perspective.

For a long time, the Italian Alps have experienced emigration; in the western parts (Piedmont [Piemonte]) from before the First World War, in the eastern parts (Veneto and Friuli) starting after the Second World War. This 'flight from the mountains' was caused by unfavourable agrosocial circumstances and the slow decline of mountain agriculture as well as the encroaching industrialisation of the Italian Alpine rim from west to east (B̈̈tZING 2003; VARotTo \& PSENner 2003). In some mountain valleys, not only the fields and meadows, but entire villages have been abandoned (STEINICKE et al. 2007).

In the 1990s, a reverse migration trend set in. More and more municipalities experience "new immigration" (BENDER \& KANITSCHEIDER 2012), the Italian Alps as a whole show a positive migration balance (BEISMANn et al. 2011). The influx municipalities are no longer only those at the Alpine rim and in the main valleys, but increasingly those at higher altitudes. This is all the more surprising as these villages are too far away from the regional urban centres for daily commuting and no new jobs have been created locally. Looking at the entire Italian Alps, we can discern a spatially fragmented pattern of demographic development. Municipalities with ongoing severe emigration and those with strong new immigration are often situated in close proximity (ISTAT 2002-2012; cf. BEISMANn et al. 2011).

The 'new inhabitants' (nuovi abitanti, CORRADo 2010) or 'voluntary mountain dwellers' (montanari per scelta, Dematteis 2011) do not form a homogenous group. They include returnees (after an active working life), immigrants - mainly from Eastern and South-Eastern Europe - and amenity migrants (PASCOLINI 2008; CorRado 2010; Dematteis 2010; Dematteis 2011). As the 'new inhabitants' are not a homogenous group, statements about the effect of their immigration are ambiguous.

For immigrants from non-EU countries, often families or family groups, affordable housing and, for some of them, job offers are what attracts them (DEMATTEIs 2010). Their immigration does not count as affluence or lifestyle migration. However, LöFFLER et al. (2011) point out that amenity migration makes up the largest proportion of migration into remote mountain areas. This type of migration seems to have its roots in multilocal living by using second homes, which has a long tradition in the Italian Alps (cf. FERrero 1998; Ferrario 2009).

As official statistics fail to capture the full picture of immigration, many studies rely on mapping newly created accommodation as their preferred method of gauging the 
extent of the 'new immigration'. However, this method is hardly able to differentiate between returnee migrants, 'classic' amenity migrants and second-home tourists. In many municipalities, more than half of the total housing stock consists of residences for these social groups. These may be renovated old buildings or new houses at the edge of the village (see Fig. 1), which can be interpreted as 'conservative' investment of

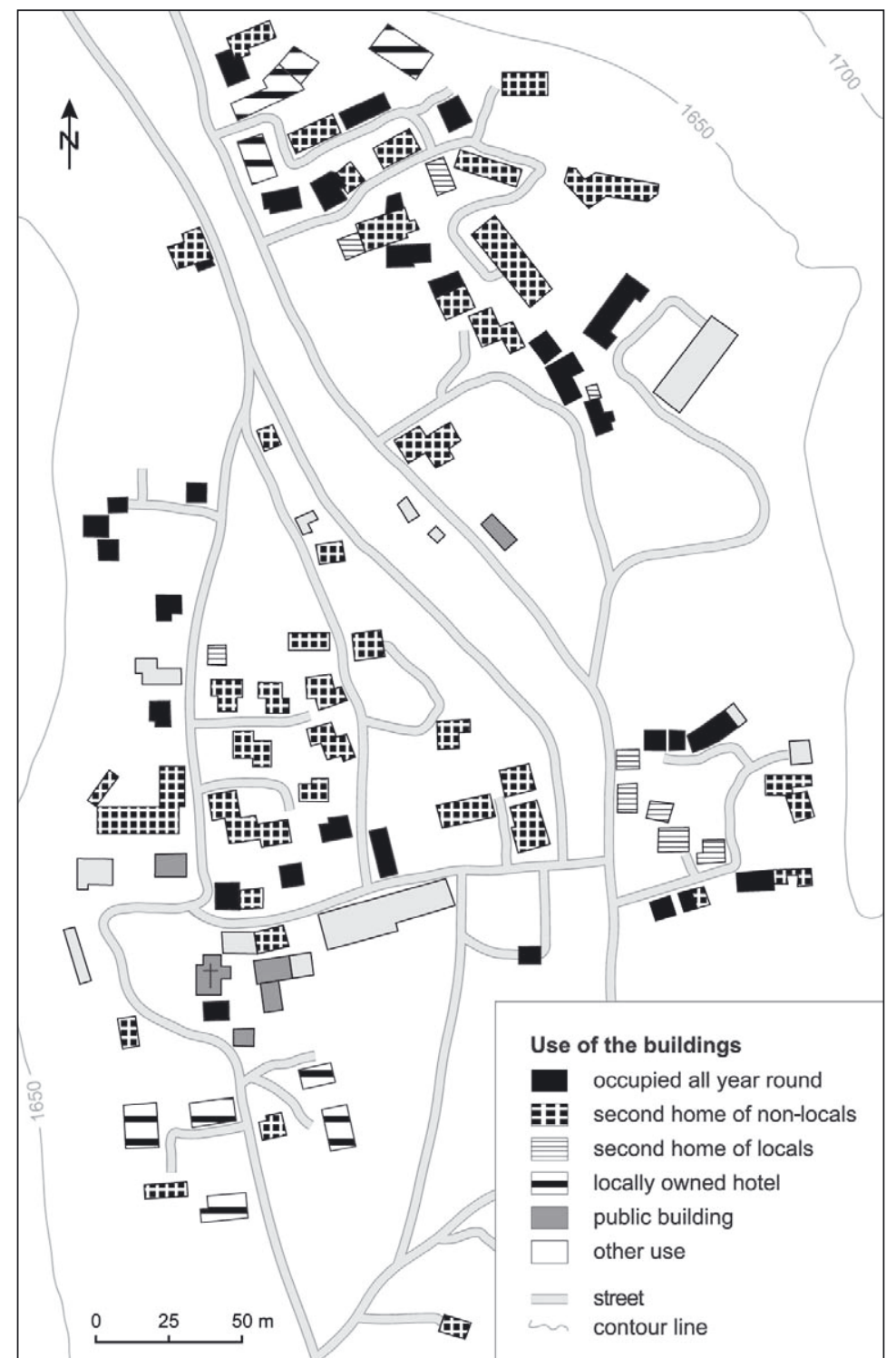

Source: Beismann et al. 2011, adapted

Fig. 1: Use of the buildings in the Walser settlement Gressoneyla-Trinité 
the middle classes or, before the European financial crisis, was seen as an "irrational" investment (FERRERO 1998, p. 62). The stays in these dwellings are lengthening and contribute to the revitalisation of the community. Some smaller villages that had been completely abandoned have been resettled and revived in this way (LöFFLER et al. 2011).

At the same time, the inflow of amenity migrants is creating new problems, not least in municipalities which had experienced decades of emigration. The autochthonous culture and especially the ethnolinguistic minorities within the Italian Alps are threatened by the influx of non-locals (STEINICKE 2007). This is unavoidable, even if the new immigrants stem from an 'enlightened' urban environment and take a strong interest in local traditions (LöFFLER et al. 2011). The threat is all the more severe if migrants come from other cultures (cf. WALDER et al. 2010) and has to be weighed against the opportunities for a new but all the more vibrant cultural development.

\subsection{East Tyrol, Austrian Alps}

In East Tyrol [Osttirol], which is part of southern Austria, i.e. situated south of the main Alpine ranges, we will analyse the phenomenon of amenity migration in relation to the demographic development (cf. BENDER \& KANITSCHEIDER 2012).

In Austria, the mountain region was predominantly settled by farmers. With the growth of tourism in the Alps, especially after the 1950s, the mountain farmers in many rural and peripheral regions let rooms to tourists to survive economically in the increasingly competitive agricultural product market (LICHTENBERGER 2000). As an example for the peripheral Alpine area, we choose the rural district East Tyrol: a region of natural beauty (part of it belongs to Hohe Tauern National Park) with low population density and intact traditional agricultural structures in many municipalities, but without the mass tourism common to other Alpine regions (BENDER 2010).

Due to the peripheral location in relation to the important urban centres with their education and employment offers and the economic structure based on agriculture and low-impact tourism, East Tyrol ranks among the emigration areas of the economically active population. The map (see Fig. 2) reveals that for the three decades from 1971 to 2001, the rural municipalities of East Tyrol (apart from the district capital Lienz and its surroundings) show clearly negative migration balances. Compared with the rest of Austria, East Tyrol is one of the most affected regions, though similar data are also found in other peripheral Eastern Alpine areas.

The negative total migration balance results from the addition of the migration balances of all age cohorts. The cohort of 15 to 44 year-olds in particular features a clearly negative balance in the district of East Tyrol $(-1.1 \%$ of the relevant age group), whereas people of $45+$ and particularly those between 55 and 74 years show a positive balance (see Fig. 3a). This age cohort comprises those migrants who are on the verge of retiring or already retired. Born (2007) devised the term "Best Age Rural Pioneers (BARPs)" for those among them who intend to migrate and in doing so, he identified a subgroup of amenity migrants, which differs from other groups in its needs and interests. 


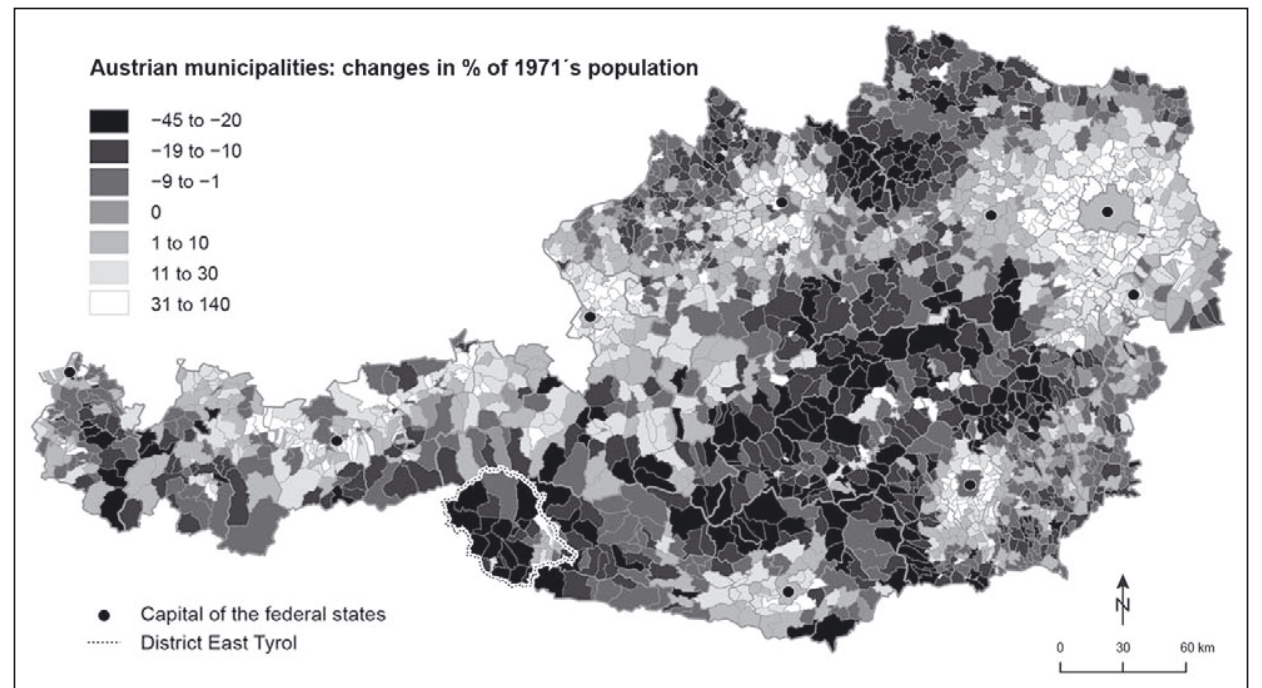

Data: ÖAW 2005; cartography: author's design 2013

Fig. 2: Migration balance from 1971-2001 in Austrian municipalities

A look on the numbers of older migrants to East Tyrol shows clearly that the migration balance of the age group 55-74 for the period from 1996 until 2010 is positive for the whole district (see Fig. 3b). Statistical data for the previous years is not available, however, a demographic study for the mountain farming area of East Tyrol realised in the 1980s shows no evidence of any immigration processes (KYTIR 1984).

Except for the years 2003 and 2004, the number of immigrants always exceeded that of emigrants. As also we know from interviews with regional stakeholders and immigrants, in parts these 55-75 year-old immigrants are returnees coming back to their native region at the end of a work life spent outside East Tyrol, re-shifting their principal residence to their former home district. On the other hand, among the immigrants are also 'real' amenity migrants, who are motivated to take up residency in particularly attractive, scenic regions towards the end of their economically active life or even afterwards. In reality, it is often not possible to differentiate clearly between these immigrant groups. Based on our personal interviews with regional experts (i.a. mayors), we estimate a share of 30-50\% for the returnees, which cannot be backed up from available statistic data, even if a more detailed breakdown would be desirable in case amenity migration is taken into account in steering regional development.

The ratio of 55+ year-olds to the total population in Austria, but also in Europe, has increased continually in recent decades ('demographic change') and will continue to do so (for the Alpine countries cf. TAPPEINER et al. 2008). This generation, on average healthier and more active than their parent generation, is very often accustomed to mobility as a result of the experiences in their working life. Additionally, a considerable part of this age cohort has above average funds at their disposal (cf. RUSPINI 2009; SANDER et al. 2010). This last characteristic makes these potential migrants 

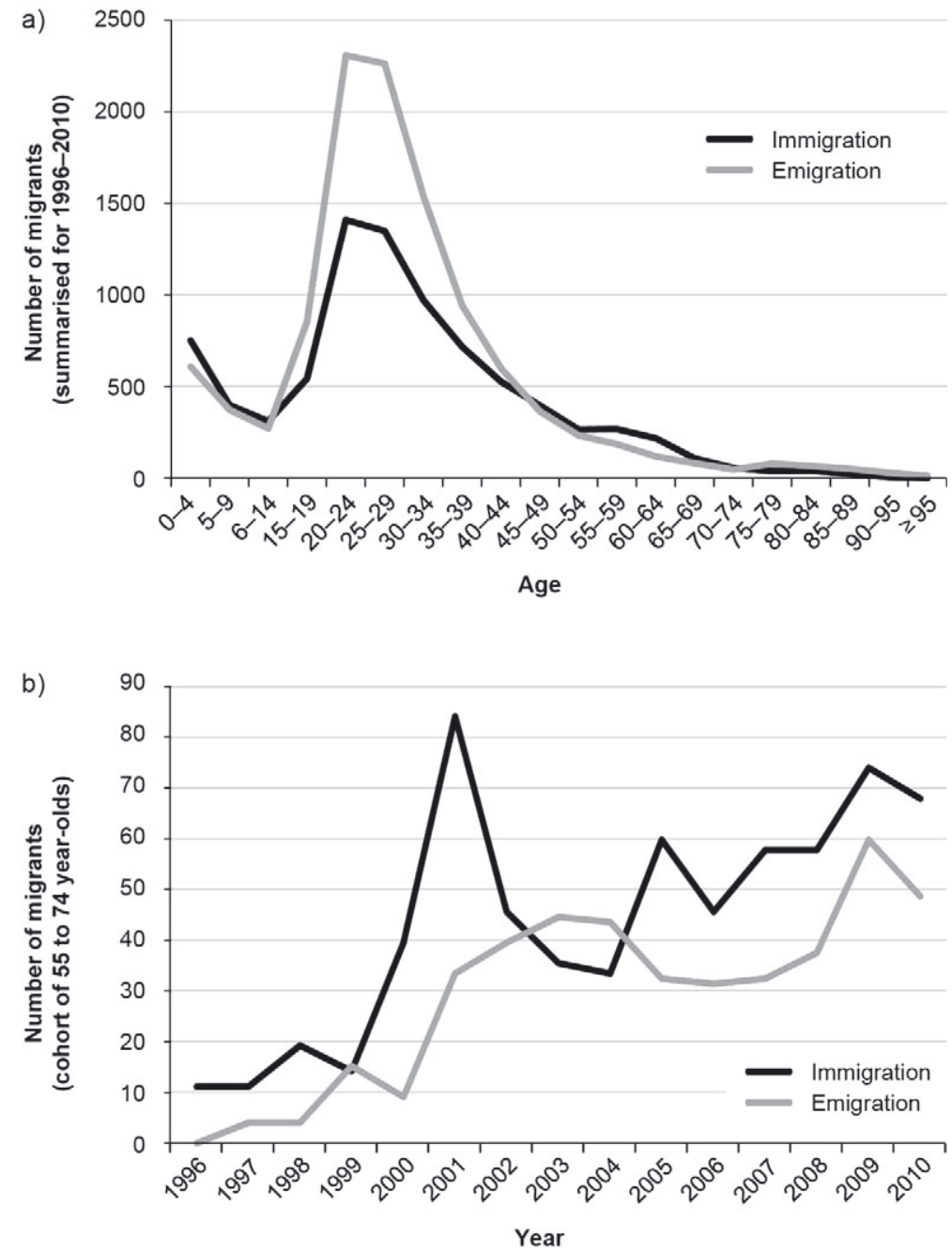

Data: Statistics Austria, Migration Statistics 1996-2010

Fig. 3 (a): Age-specific migration balance summarised for 1996-2010 in the district of East Tyrol. (b): Migration balance from 1996-2010 for the age cohort of 55 to 74 year-olds in the district of East Tyrol

an economic factor of interest for rural regions suffering from the emigration of the young and well educated (cf. BORN 2007). For the 75+ age group, however, a negative migration balance can be observed in nearly all rural regions of Austria (cf. Fig. 3a), a situation that MARIK-LEBECK \& WisBAUER (2009) explain with reference to the inadequate health service provision for this age group. In very many cases amenity migration clearly does not represent a permanent shift of domicile. 


\subsection{Chilean Andes}

For the case studies in the Chilean Andes, the quantitative and qualitative methods allowed an estimate of the dimension of amenity migration in mountain areas.

In Chile, since its colonial beginning, the large land owners were obliged to live in the cities, their rural estates (fundos) were pleasant places for weekends and vacations. In the $19^{\text {th }}$ century, the rich installed second homes, but at first they preferred the seaside. Only with mountaineering (initiated by foreigners and the German colony in Chile) the Andes became attractive in the late $19^{\text {th }}$ century. Mountain tourism was initiated also mostly by Germans and their descendants, and some rich metropolitan people installed second homes in mountain areas (Borsdorf \& Hidalgo 2009a; cf. ERIKSEN 1970 for the Argentinian Andes).

BorsDorf \& HidALGO (2009a and b) carried out a qualitative research in the Chilean part of the Andes, based on two case studies. Both case study areas are situated in the central zone of Chile, at 50 and $80 \mathrm{~km}$ distance from the two large agglomerations Santiago and Valparaíso, former dwelling places of most amenity migrants in both areas. Maipó Valley, at an altitude of about $960 \mathrm{~m}$ in the High Cordillera, offers high-mountain scenery, whereas in Olmué, at about $300 \mathrm{~m}$ on the western slope of the coastal range, we find Mediterranean mountain scenery. The third Chilean case study was carried out by Hidalgo \& Zunino (2011) in Pucón, a Patagonian town in the south-Chilean region of Araucanía. Its position on the banks of Lake Villarica, at the foot of the volcano of the same name, combines a pleasant climate with high mountain scenery.

Amenity migration in the three Chilean case studies is closely linked with the tourism in each municipality. The longer tourism has existed in a place, the earlier immigration of new permanent settlers started. Usually a marked improvement in the transport infrastructure is the decisive factor - for instance, the construction of the railway around 1930 in Pucón (Zunino \& Hidalgo 2010) or in 1906 in San José del Maipó (Hidalgo et al. 2009). By contrast, in Olmué, amenity migration did not start until 1992 and has gained in importance since 2002.

It was only in the last two decades that amenity migration reached significant numbers. Between 1992 and 2002 the population of Pucón rose from 14,356 to 21,107 (INE 1992 and 2002); the forecast for 2012 is 33,335 inhabitants (INE 2012). Between 2002 and 2009 another 1,772 new housing units, most of them single family dwellings outside the city area, were constructed (Hidalgo \& Zunino 2011). Chilean statistics do not allow a precise identification of amenity migrants, but feasible estimates can be derived from migration figures and the number of constructed housing units. Based on official statistics, Borsdorf \& HidALGo (2009b) mapped the migration flows (see Fig. 4) and estimated a proportion of 30\% (Maipó Valley) and 20\% (Olmué) amenity migrants of the total population being in 2009 .

The motives (pull factors) of the amenity migrants in all three case studies are very similar: the natural and cultural amenities as well as the landscape and climatic amenities of the location were mentioned most often by the migrants. There are, however, additional motives that allow a differentiation of subtypes of amenity migrants. 


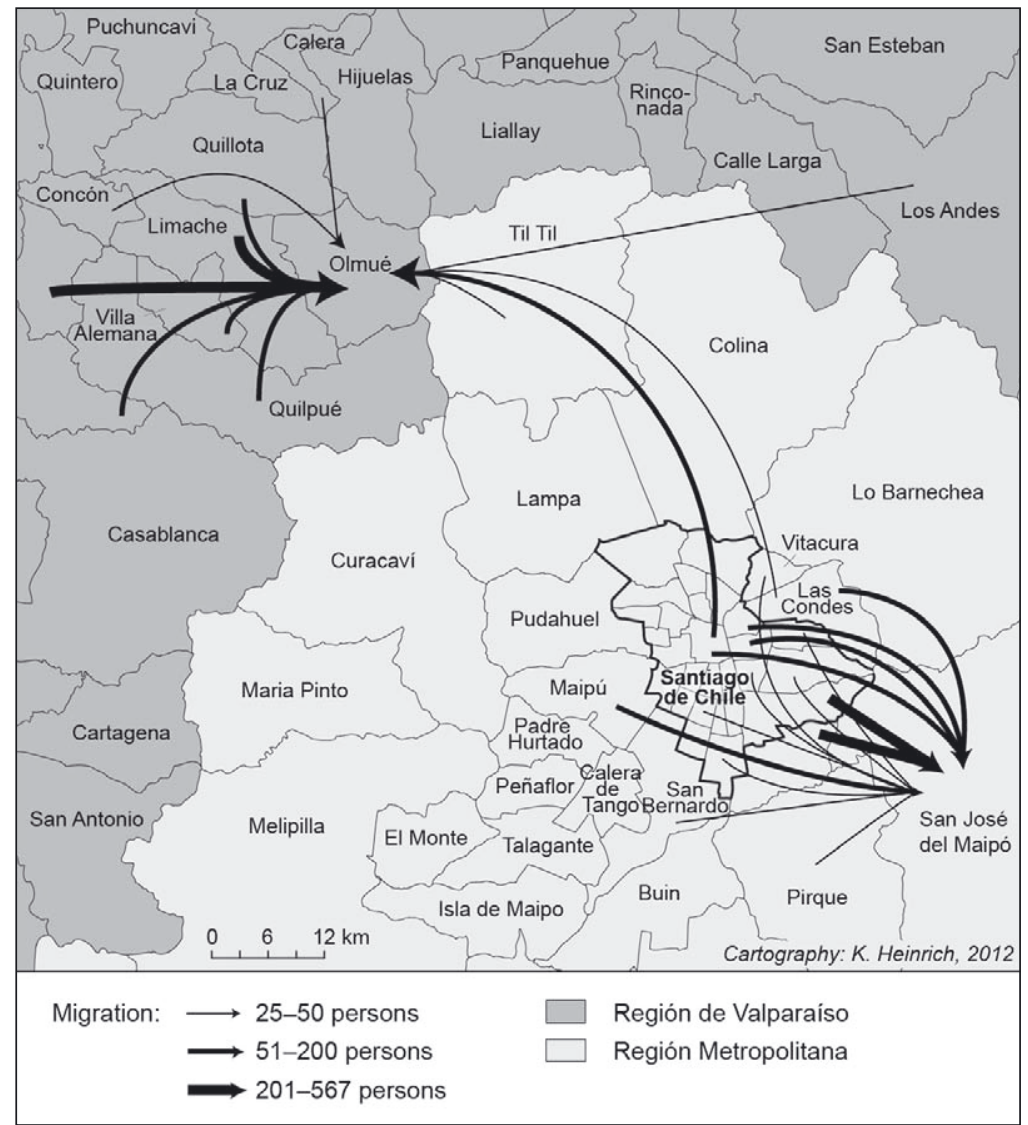

Source: Borsdorf \& HidALGo 2009b, adapted

Fig. 4: Migration flows from Santiago to Olmué and the Maipó Valley, 1997-2002

'Green amenity migrants' (Migrantes de amenidad verdes, MAV), for instance, are looking for an alternative lifestyle in a symbiotic integration of their community with nature (ZuNiNO \& HidALGO 2010).

The later the process of amenity migration reaches significant quantity in a place, the more it is shaped by real estate developers. Maipó is least developed in this respect, in Olmué the migration process is partly controlled by real estate developers, in Pucón the enormous growth can only be explained with references to real estate megaprojects. In Chile such megaprojects represent a great risk for urban sprawl. Agricultural land is bought up by investors and may be resold in plots of at least $5,000 \mathrm{~m}^{2}$ (parcelas de agrado) to people interested in building on this land. In the medium term, this could cost the municipalities the basis for both tourism and amenity migration (HIDALGO \& Zunino 2011). 


\subsection{Argentinian Andes}

For the Argentinian Andes, case studies focused on the local economic development of the tourist destinations affected by amenity migration.

All three studies, which capture a total of five municipalities, use a qualitative approach and therefore do not allow exact statements about the dimension of amenity migration. What the villages of San Martín de los Andes (SMA) (OtERo et al. 2006; GonzÁlez et al. 2009), Villa La Angostura (VLA), El Bolsón (EB), Lago Puelo (LP) (GonZÁlez et al. 2009) and Caviahue (CAV) (SÁNCHEZ \& GonZÁlez 2011) have in common is their location in Neuquén province or immediately south (LP), in a mountainous landscape with characteristic lakes near the Chilean border, where the main earnings come from (seasonal) tourism.

The first amenity migrants arrived shortly after these places had established themselves as tourist destinations, in SMA as early as the 1930s (ERIKSEN 1970; Otero et al. 2006). In VLA the boom did not start until after the Argentinian state crisis of 2001, when many people decided to invest in real estate (GonZÁLEZ et al. 2009). The little village of Caviahue, founded as late as 1986 as a tourist resort, experienced amenity migration in significant numbers from 2002, as a result of investment incentives issued by the province and the municipality (SÁnCHEZ \& GonZÁlez 2011). Like in Chile, the share of amenity migrants can be estimated for Argentina too on the basis of the aggregated migration numbers in the census data. A breakdown by age of migration into SMA shows a negative migration balance for people under 30, against a distinctly positive migration balance for the cohorts of the 30-39, 40-49 and 50-59 year olds (ОтеRо et al. 2006). In Argentina the amenity migrants' usual motives for moving are augmented by push factors for people looking for peace and quiet (OTERO et al. 2006). These are the changing political frameworks, particularly the terror of the military dictatorship in the 1970s, which affected large cities the most, and the economic uncertainties after the crisis of 2001.

All studies agree on the lack or absence of integration of the newcomers in their destinations. For SMA, OTERO et al. (2006) even found splits and segregated groups within the amenity migrants by date of arrival, origin or motive for the move. Some of the reasons for the integration deficits clearly lie with the indigenous population who regards the migrants as economic competition, either for jobs or for tourists, when the existing, oversized tourist infrastructure is expanded further by new accommodation built by the amenity migrants (SÁNCHEZ \& GonZÁlez 2011; GonZÁlez et al. 2009). At the same time, affluent in-migrants bring with them an urban lifestyle that they want to continue in the new rural environment, which leads to demands on the (scarce) local resources, infrastructure and leisure options. Respondents mentioned rising real estate prices (OTERO et al. 2006), significant displacement of the local population from the town centre (GONZÁLEZ et al. 2009 talk of roughly half of the VLA population pushed to the periphery through new real estate projects of the newcomers), widespread and unpunished violation of building regulations and spatial planning, which leads to urban sprawl and threatens the tourist activities (SÁNCHEZ \& GonZÁlez 2011).

Respondents did, however, also mention positive effects of amenity migration (inflow of capital and job creation, as well as special appreciation of the landscape) 
(OTERo et al. 2006). This view might be influenced by the fact that in the villages of the study amenity migrants make up a significant proportion of the population.

\section{Discussion: Comparing the southern European Alps and southern Andes}

As seen in the case studies cited above, similar amenity migration processes are going on in both Andes and Alps. Coming back to the research questions, we can state that the amenity migration phenomenon exists in both Alps and Andes with very similar characteristics. The starting dates in the different regions vary from the 1970 s to the early 1990s - but in all case studies we identified an increased significance since the turn of the century. Quantifying the intensity of amenity migration turned out to be difficult because the phenomenon cannot be differentiated from other migration processes in the official statistics without carrying out qualitative research on-site. Besides, in those case studies where such field work has been done, there are considerable variations in the intensity of the process as well as regarding the different types of amenity migrants.

The quantitative part of studies on amenity migration is plagued by the general problem that official statistics provide at most data on age and/or origin of the migrants, not on the motives. As migration is often concentrated in certain age groups (cf. East Tyrol) and most of the elderly are unlikely to have moved for a new job, their migration may be interpreted as amenity-led (allowing for some uncertainty). The biggest uncertainty is deciding whether the mostly social pull factors of remigrations should be considered as amenities; in spite of that, remigrations may occur at all ages for "lifestyle reasons" (Gibson \& McKenzie 2009, p. 4; cf. Chipeniuk 2008).

East Tyrol is typical within Austria for a certain type of region (districts) with immigration of older people (after data from Statistics Austria 1996-2010). We know that, traditionally, older amenity migrants in Austria tend to go for well-established tourist hotspots (BENDER \& KANITSCHEIDER 2012). The example of East Tyrol may serve as a case in point for assessing the amenity migration potential of peripheral and less touristically developed areas.

In southern Latin America the demographic change is far less advanced than in Europe but shows a similar trend. Sinking birth rates, which means a transition from a population pyramid to an urn shape, can only be observed since the new millennium, older year groups are relatively weak (GANS \& Gonzáles LeIva 2004). This general observation matches those of Argentinian studies that amenity migrants in the Andes are younger on average than those in the Alps. The older cohorts, however, by now include a significant number of affluent people (cf. Astorga et al. 2005), which explains why the elderly are a growing group within the amenity migrants in the Andes as well. This trend will also depend on the extent to which the destination regions are able to meet the infrastructural and social needs of older in-migrants.

When we analyse the push factors (making the migrants leave their former residence) and the pull factors (motivating them to move to the amenity place), we find 
more similarities than differences between Andes and Alps. The reasons mentioned for leaving the urban environment are natural conditions (e.g. smog, pollution, traffic noise, also the artificial surrounding), social conditions (e.g. anonymity, in some cases crime) and finally spatial conditions (e.g. lack of open spaces, standardised architecture, traffic jams). Compared to the urban space, the amenity destination offers favourable natural, social and spatial conditions (e.g. natural beauty, local climate, clean air, quiet, 'wilderness'; social contacts, safety; attractive leisure surroundings, individual architecture, low distances to local centres) (HidALGo et al. 2009; LöFFLER et al.2011). Some of these factors, especially the crime/safety argument, seem to be more significant in the Andes, as crime is perceived to be a major threat in the agglomerations. However, the comparison of the case studies shows that in the Andes amenity migrants tend to construct new, modern buildings (mostly single-family homes) on undeveloped land - or to buy such buildings from the real estate developers, whereas in the Alps there is a trend towards renovating dilapidated, abandoned buildings in traditional villages (cf. HidAlgo et al. 2009; LöfFLER et al. 2011). These are clearly two variants of a 'conservative' investment in real estate.

There is also agreement in the case studies concerning the facilitators of amenity migration, some of them even sine qua nons: accessibility of the remote mountain areas, telecommunication infrastructure and availability of land in the target areas, wealth and reduced socio-spatial rootedness by the amenity migrants, and, in the case of non-retirees, the option of working from home or even local jobs (BORSDORF \& HIDALGO 2009b; LÖFFLER et al. 2011). Differences in the spatial distribution of amenity migration can be explained with reference to the attractiveness of potential destinations. Denser settlement and comparatively good transport and other infrastructure in Alpine valleys encourage a more dispersed immigration to this area, compared to the southern Andes.

\section{Conclusion and brief outlook: Opportunity or risk for a sustainable local development?}

The concept of sustainable regional development implies, following the Brundtland Report (WCED 1987), that economic activities, social coexistence and ecological impacts are rated with respect to the least negative effect on future generations. In many respects, the amenity migration process meets the requirements of sustainable development and shows a positive impact in the region. It creates local jobs, not only short-term ones in construction (for local traders or as employees of large real estate developers), but also in services. Older immigrants especially offer the prospect of economic diversification for the region. Without competing on the local labour market, BARPs bring in additional demand for products and services, often in combination with a special interest in local, sustainable goods (LöFFLER et al. 2011; cf. BORN 2007).

Often job seekers will follow amenity migrants. A dispersed amenity migration, as seen in large parts of the Alps, should boost the local economies in particular; the more concentrated migration in the southern Andes should introduce more new economic 
players. A 'consumption-led' residential mobility may be followed by a 'productionled' one (Williams \& Hall 2002).

Due to the immigration, the purchasing power within the region is strengthened and taxes for the municipality will rise. Because of heterogeneity between in- and out-migrants this could be true also in cases where net migration is strongly negative (cf. Østbye \& Westerlund 2007). However, this is only fully true where the majority of amenity migrants have created permanent residences. Second homes mainly incur high infrastructure costs while the added value for local communities remains relatively low (see CIPRA 2008).

The infrastructure and service demand of tourists, who generally travel for shorter recreational stays, differs partly from that of immigrants, even within the same age group. On the one hand, this results from the ongoing necessity to meet all daily needs at the place of residence. With health service provision in particular, elder migrants often develop special requirements only after their migration to an amenity place. On the other hand, it is a consequence of the interest in social interaction at the adopted home. Especially if a particular region has been carefully chosen as the place of permanent residence, it can be assumed that the interest in the place and its inhabitants is above average (LÖFfLER et al. 2011).

To a certain degree, the migration to remote areas might offset a rural exodus which was observed before, for example in large parts of the southern Alps. However, in most cases amenity migration can neither stop the emigration of young people interested in education nor compensate qualitatively for the age-selective migration from remote areas, especially where a considerable part of the amenity migrants are retirees. This means that the contribution of amenity migration to a sustainable demographic development is minimal. On the other hand, larger numbers of in-migrants from elsewhere (not returnees), even if they are sympathetic to the local culture, present a certain risk of 'external imposition' for the indigenous population.

Beyond that we can identify several negative impacts detracting from sustainable development induced by amenity migration. The rising demand for houses and properties leads to an increase in real estate prices, in the worst case to the point where locals cannot afford it any more (cf. GOBER et al. 1993; OTERO et al. 2006). In developing areas, very often there is a lack of development concepts, leading to disintegrated and disharmonic urban structures (Gonzélez et al. 2009). Soil sealing, land consumption and therefore loss of agricultural land, rural sprawl, increased water and energy consumption are potential areas of conflict in the especially sensitive mountainous areas (Hidalgo \& Zunino 2011). Social segregation or a general lack of interest in integration on the part of the migrants does not support local social cohesion. PERLiK (2011, p. 4) emphasises that "dwelling in the mountains is not a tendency of rural life but an urban attitude in provenance and character".

The authors of the Argentinian studies generally agree that amenity migration without regulation represents a negative side effect (for the locals) of tourism in the study areas; GoNZÁLEZ et al. (2009, p. 89) call amenity migration "la sombra del turismo", 'the shadow of tourism'.

Considering the potentially positive and negative aspects of amenity migration, it seems to bring about a double-edged process for the migrants' target areas. The 
sustainability of the local development depends on how carefully vulnerabilities are recognised and mitigated. With forward strategies and a sound development plan (cf. GLORIOSO 2009), the positive impulses might outweigh the disadvantages for remote mountain areas.

\section{References}

Astorga P., Berges A.R., Fitzgerald V. (2005), The standard of living in Latin America during the twentieth century. In: Economic History Review, 58, 4, pp. 765-796.

Austrian AcAdemy of Sciences (ÖAW) (2005), GALPIS-Web. - www.galpis.at (Accessed on 29 April 2013).

BÄtZING W. (2003), Die Alpen: Geschichte und Zukunft einer europäischen Kulturlandschaft. München, Beck.

Beismann M., Löffler R., Walder J., Steinicke E. (2011), Amenity Migration und ethnolinguistische Minderheiten in den italienischen Alpen. Ein Zwischenbericht. In: INNSBRUCKER Geographische Gesellschaft (ed.), Innsbrucker Jahresbericht 2008-2010, pp. 23-36. Innsbruck, University of Innsbruck.

Bender O. (2010), Entstehung, Entwicklung und Ende der alpinen Bergbauernkultur. In: HeLLER H. (ed.), Über das Entstehen und die Endlichkeit physischer Prozesse, biologischer Arten und menschlicher Kulturen (= Matreier Gespräche zur Kulturethologie, 2009), pp. 113-137. Wien - Berlin, LIT.

Bender O., Kanitscheider S. (2012), New Immigration into the European Alps: Emerging Research Issues. In: Mountain Research and Development, 32, 2, pp. 235-241.

BERRY B .J.L. (1980), Urbanization and Counterurbanization in the United States. In: The Annals of the American Academy of Political and Social Science, 451, pp. 13-20.

Bloom D.E., Canning D. (2004), Global Demographic Change: Dimensions and Economic Significance (= NBER Working Paper, 10817). Cambridge, National Bureau of Economic Research. - http://www.nber.org/papers/w10817 (Accessed on 29 April 2013).

Born K.M. (2007), Zuwanderungen in den peripheren ländlichen Raum. Eine Chance? In: ScHMIED D., Henkel G. (eds.), Leerstände von Gebäuden in Dörfern: Beginn der Dorfauflösung oder Chancen durch Umnutzung?, pp. 19-36. Göttingen, Cuvillier.

Borsdorf A., Hidalgo R. (2009a), Pleasure lots near Santiago de Chile and Valparaíso: Amenity migration the Chilean way. In: Moss L.A.G., Glorioso R.S., Krause A. (eds.), Understanding and Managing Amenity-led Migration in Mountain Regions. Proceedings of the conference in Banff, Alberta, Canada, May 15-19, 2008, pp. 118-130. Banff, The Mountain Centre.

Borsdorf A., Hidalgo R. (2009b), Searching for Fresh Air, Tranquillity and Rural Culture in the Mountains: A New Lifestyle for Chileans? In: Die Erde, 140, 3, pp. 275-292.

Chaverri P. (2006), Cultural and Environmental Amenities in Peri-urban Change: the Case of San Antonio de Escazú, Costa Rica. In: Moss L.A.G. (ed.), The Amenity Migrants. Seeking and Sustaining Mountains and their Cultures, pp. 187-199. Wallingford, CABI.

Chipeniuk R. (2005), Planning for Rural Amenity Migration. In: Plan Canada (Ottawa), 45, 1, pp. 367-380.

Chipeniuk R. (2008), Defining amenity migration. Results from a Survey of Experts (Participants in the understanding and managing amenity-led migration in Mountain Regions Conference, Banff, Alberta, Canada, 2008 May 15-19). - http://www.banffcentre.cal 
mountainculture/mtnconferences/am/pdf/survey-results_defining-am-and-am-migrants. $p d f$ (Accessed on 29 April 2013).

CIPRA International (ed.) (2008), Herausforderung Zweitwohnung - Viel Raum für wenig Nutzen (= CIPRA-Info, 87). Schaan, CIPRA.

Cognard F. (2006), Le rôle des recompositions sociodémographiques dans les nouvelles dynamiques rurales: l'exemple du Diois. In: Méditerranée, 107, pp. 5-12.

Corrado F. (ed.) (2010), Ri-abitare le Alpi. Nuovi abitanti e politiche di sviluppo. Genova, Eidon.

Dematteis G. (ed.) (2011), Montanari per scelta. Indizi di rinascita nella montagna piemontese. Milano, Franco Angeli.

Dematteis M. (2010), Mamma li turchi. Le comunità straniere delle Alpi si raccontano. Roccabruna, Chambra d'Oc.

ERIKSEN W. (1970), Kolonisation und Tourismus in Ostpatagonien (= Bonner Geographische Abhandlungen, 43). Bonn, Ferdinand Dümmler.

Ferrario V. (2009), Rural/leisure landscapes and amenity-led migration. An example in the Eastern Alps. In: Moss L.A.G., Glorioso R.S., Krause A. (eds.), Understanding and Managing Amenity-led Migration in Mountain Regions. Proceedings of the conference in Banff, Alberta, Canada, May 15-19, 2008, pp. 107-117. Banff, The Mountain Centre.

FERRERo G. (1998), Seconde case, politiche urbanistiche e turismo nelle Alpi occidentali italiane. In: Revue de géographie alpine, 86, 2, pp. 61-68.

Fourny M.-C. (1994), Nouveaux habitants dans un pays de moyenne montagne. In: Études rurales, 135/136, pp. 83-95.

Gans P., Gonzáles Leiva J.I. (2004), Der chilenische Zensus von 2002 - erste Ergebnisse. In: Geographische Rundschau, 56, 3, pp. 56-58.

Garín Contreras A., Albers C. (2011), Dinámicas socio demográficas en el mundo rural de la Araucanía. In: Revista Geográfica de América Central, 2/47E, pp. 1-14.

Gibson J., McKenzie D. (2009), The Microeconomic Determinants of Emigration and Return Migration of the Best and Brightest. Evidence from the Pacific (= Policy Research Working Paper, 4965). Washington, DC, The World Bank. - http://elibrary.worldbank. org/content/workingpaper/10.1596/1813-9450-4965 (Accessed on 29 April 2013).

GLoRIoso R.S. (2009), Toward a Strategy for Managing Amenity Migration: The Role of Multiple Future Scenarios. In: Die Erde, 140, 3, pp. 293-315.

Glorioso R.S., Moss L.A.G. (2007), Toward a Strategy for Amenity Migration to Mountain Regions: Current Knowledge and a Strategic Construct for Sustainable Management. In: Social Change, 37, 1, pp. 137-161.

Gober P., McHugh K., LeCLerC D. (1993), Job-rich but housing poor: the dilemma of the western amenity town. In: Professional Geographer, 45, 1, pp. 12-20.

González R., Otero A., Nakayama L., Marioni S. (2009), Las movilidades del turismo y las migraciones de amenidad: problemáticas y contradicciones en el desarrollo de centros turísticos de montaña. In: Revista de Geografía Norte Grande, 44, pp. 75-92.

Grau H.R., Aide T.M. (2007), Are Rural-Urban Migration and Sustainable Development Compatible in Mountain Systems? In: Mountain Research and Development, 27, 2, pp. 119-123.

Graves P.E. (1980), Migration and Climate. In: Journal of Regional Science, 20, 2, pp. 227-237.

Hidalgo R., Borsdorf A., Plaza F. (2009), Parcelas de agrado alrededor de Santiago y Valparaíso. ¿Migración por amenidad a la chilena? In: Revista de Geografía Norte Grande, 44, pp. 93-112.

Hidalgo R., Zunino H.M. (2011), Negocios inmobiliarios en centros turísticos de montaña y nuevos modos de vida. El papel de los migrantes de amenidad existenciales en la Comuna de Pucón - Chile. In: Estudios y Perspectivas en Turismo, 20, pp. 307-326. 
Instituto Nacional de Estadísticas (INE) (1992), XVI Censo Nacional de Población y Vivienda 1992. Santiago de Chile, INE.

Instituto Nacional de Estadísticas (INE) (2002), XVII Censo Nacional de Población y Vivienda 2002. Santiago de Chile, INE.

Instituto Nacional de Estadísticas (INE) (2012), Proyecciones de Población. - http://www.ine. cl/canales/chile_estadistico/demografia_y_vitales/proyecciones/proyecciones_poblacion. zip (Accessed on 29 April 2013).

L'Istituto Nazionale di Statistica (ISTAT) (2002-2012), Demografia in Cifre. Popolazione residente. Bilancio demografico. - http://demo.istat.it/ (Accessed on 29 April 2013).

Kahsai M.S., Schaeffer P.V. (2010), Deconcentration, Counter-Urbanization, or Trend Reversal? The Population Distribution of Switzerland, Revisited. In: The Open Urban Studies Journal, 3, pp. 89-102.

KYTIR J. (1984), Demographischer Wandel im Bergbauernraum: Das Beispiel der oberen Iselregion in Osttirol. In: Husa K., Vielhaber C., Wohlschlägl H. (eds.), Beiträge zur Bevölkerungsforschung. Festschrift Ernest Troger zum 60. Geburtstag, pp. 59-74. Wien, Hirt.

Lichtenberger E. (2000), Austria. Society and Regions. Vienna, Austrian Academy of Sciences Press.

LÖFfler R., Steinicke E. (2006), Counterurbanization and its Socioeconomic Effects in High Mountain Areas of the Sierra Nevada (California/Nevada). In: Mountain Research and Development, 26, 1, pp. 64-71.

LÖFfler R., SteInICKe E. (2007), Amenity Migration in the U.S. Sierra Nevada. In: Geographical Review, 97, 1, pp. 67-88.

Löffler R., Beismann M., Walder J., Steinicke E. (2011), New demographic developments and their cultural impact on the Italian Alps. In: Borsdorf A., STÖtter J., Veuillet E. (eds.), Managing Alpine Future II. Proceedings of the Innsbruck Conference, November 21-23, 2011, pp. 381-393. Innsbruck, Austrian Academy of Sciences.

Marik-Lebeck S., Wisbauer A. (2009), Die Jungen ziehen in die Stadt, die Alten aufs Land. Österreichs Binnenwanderungen 2002 bis 2007 auf Gemeindeebene. In: Kommunal, 3, pp. 30-34.

McIntyre N. (2009), Rethinking Amenity Migration: Integrating Mobility, Lifestyle and SocialEcological Systems. In: Die Erde, 140, 3, pp. 229-250.

Moss L.A.G. (1994), Beyond tourism: the amenity migrants. In: MannermaA M., InAYATULlah S., Slaughter R. (eds.), Coherence and Chaos in Our Uncommon Futures: Visions, Means, Actions. Selections from the XIII World Conference of the World Futures Studies Federation, August 23-27, 1993 in Turku, pp. 121-128. Turku, Turku School of Economics.

Moss L.A.G. (ed.) (2006), The Amenity Migrants. Seeking and Sustaining Mountains and their Cultures. Wallingford, CABI.

Moss L.A.G., Glorioso R.S., Krause A. (eds.) (2009), Understanding and Managing Amenityled Migration in Mountain Regions. Proceedings of the conference in Banff, Alberta, Canada, May 15-19, 2008. Banff, The Mountain Centre.

Nakayama L., Marioni S. (2007), Migración por opcion: el fenómeno migratorio en destinos turísticos de montaña. In: Revista Brasileira de Pesquisa em Turismo, 1, 2, pp. 101-136.

Otero A., Nakayama L., Marioni S., Gallego E., Lonac A., Dimitriu A., González R., Hosid C. (2006), Amenity migration in the Patagonian Mountain Community of San Martín de los Andes, Neuquén, Argentina. In: Moss L.A.G. (ed.), The amenity migrants. Seeking and sustaining mountains and their cultures, pp. 200-211. Wallingford, CABI.

Østbye S., Westerlund O. (2007), Is Migration Important for Regional Convergence? In: Regional Studies, 41, 7, pp. 901-915. 
Pascolini M. (ed.) (2008), Le Alpi che cambiano. Nuovi abitanti, nuove culture, nuovi paesaggi. Belluno - Udine, Forum.

Perlik M. (2006), The Specifics of Amenity Migration in the European Alps. In: Moss L.A.G. (ed.), The Amenity Migrants: Seeking and Sustaining Mountains and Their Cultures, pp. 215-231. Wallingford, CABI.

PerLIK M. (2007), Stadt- und Industrieentwicklung in europäischen Gebirgsräumen. In: BorsdorF A., GrabHerR G. (eds.), Internationale Gebirgsforschung (= IGF-Forschungsberichte, 1), pp. 115-128. Innsbruck, Austrian Academy of Sciences.

PERLIK M. (2011), Alpine gentrification: The mountain village as a metropolitan neighbourhood. New inhabitants between landscape adulation and positional good. In: Revue de géographie alpine [online], 99, 1. - http://rga.revues.org/index1370.html (Accessed on 29 April 2013).

Phillips M. (1993), Rural gentrification and the processes of class colonization. In: Journal of Rural Studies, 9, 2, pp. 123-140.

Ruspini P. (2009), Elderly Migrants in Europe: An Overview of Trends, Policies and Practices. Report prepared in 2009 for the European Committee on Migration of the Council of Europe (CDMG). - http://www.cermes.info/upload/docs/Elderly_migrants_in_Europe _paolo_ruspini_14_07_10.pdf (Accessed on 29 April 2013).

SÁnchez L., González R. (2011), Destinos turísticos de montaña con migración de amenidad. Implicancias en el desarrollo turístico local - Caso Caviahue, Argentina. In: Estudios y Perspectivas en Turismo, 20, pp. 288-306.

Sander N., Skirbekk V., Kc S., Lundevaller E. (2010), Prospects for later-life migration in urban Europe (= PLUREL Report D1.2.4, Module 1: Driving forces and global trends). - http://www.plurel.net/images/D124.pdf (Accessed on 29 April 2013).

Statistics Austria (1996-2010), Migration Statistics. Vienna. (Unpublished data)

STEINICKe E. (2007), The impact of current demographic transformation on ethno-linguistic minorities in the Alps. In: Borsdorf A., Stötter J., Veulliet E. (eds.), Managing Alpine Future. Proceedings of the Innsbruck Conference, October 15-17, 2007, pp. 243-252. Innsbruck, Austrian Academy of Sciences.

Steinicke E., Löffler R. (2007), Amenity Migration. Die neuen Bewohner der Alpen. Skizze eines Forschungsprojektes. In: Innsbrucker Geographische Gesellschaft (ed.), Alpine Kulturlandschaft im Wandel. Hugo Penz zum 65. Geburtstag, pp. 213-225. Innsbruck, Innsbruck University Press.

Steinicke E., Ciarasuolo L., Čede P. (2007), “Ghost towns” nelle Alpi Orientali. Il fenomeno dello spopolamento nella zona montuosa del Friuli. In: Rivista Geografica Italiana, 114, 4, pp. 549-570.

Steinicke E., ČEde P., Fliesser U. (2010), Development Patterns of Rural Depopulation Areas: Demographic Impacts of Amenity Migration on Italian Peripheral Regions. In: Mitteilungen der Österreichischen Geographischen Gesellschaft, 151, pp. 195-214.

Stewart S.I. (2002), Amenity Migration. In: Luft K., MacDonald S. (eds.), Trends 2000: Shaping the future. $5^{\text {th }}$ Outdoor recreation and tourism trends symposium, $2000 \mathrm{Sept}$. 17-20, Lansing, MI, pp. 369-378. East Lansing, MI.

TAPpeiner U., Borsdorf A., TAsser E. (eds.) (2008), Alpenatlas - Atlas des Alpes - Atlante delle Alpi - Atlas Alp - Mapping the Alps. Heidelberg, Spektrum Akademischer Verlag.

Varotto M., Psenner R. (eds.) (2003), Spopolamento montano: cause ed effetti. Entvölkerung im Berggebiet: Ursachen und Auswirkungen. Schriften der Tagung in Belluno (Crepadona, 13. Oktober 2001) und der Tagung in Innsbruck (Claudiana, 14.-16. November 2002). Belluno - Innsbruck, Fondazione Giovanni Angelini. 
W Alder J., Löffler R., Steinicke E. (2010), Autochthone ethno-linguistische Minderheiten in den italienischen Alpen im Lichte des aktuellen demographischen Wandels. In: Europa Regional, 16, 4, pp. 178-190.

Weichhart P. (2009), Multilokalität - Konzepte, Theoriebezüge und Forschungsfragen. In: Informationen zur Raumentwicklung, 1-2, pp. 1-14.

Williams A.M., Hall C.M. (2002), Tourism, migration, circulation and mobility: the contingencies of time and place. In: Hall C.M., Williams A.M. (eds.), Tourism and Migration: New Relationships between Production and Consumption, pp. 1-52. Dordrecht, Kluwer.

World Commission on Environment and Development (WCED) (1987) (ed.), Our Common Future. Oxford, Oxford University Press.

Zunino H.M., Hidalgo R. (2010), En busca de la utopía verde: migrantes de amenidad en la comuna de Pucón, IX Región de la Araucanía, Chile. Scripta Nova. In: Revista Electrónica de Geografía y Ciencias Sociales, XIV, 331, 75. - http://www.ub.edu/geocrit/ sn/sn-331/sn-331-75.htm (Accessed on 29 April 2013). 